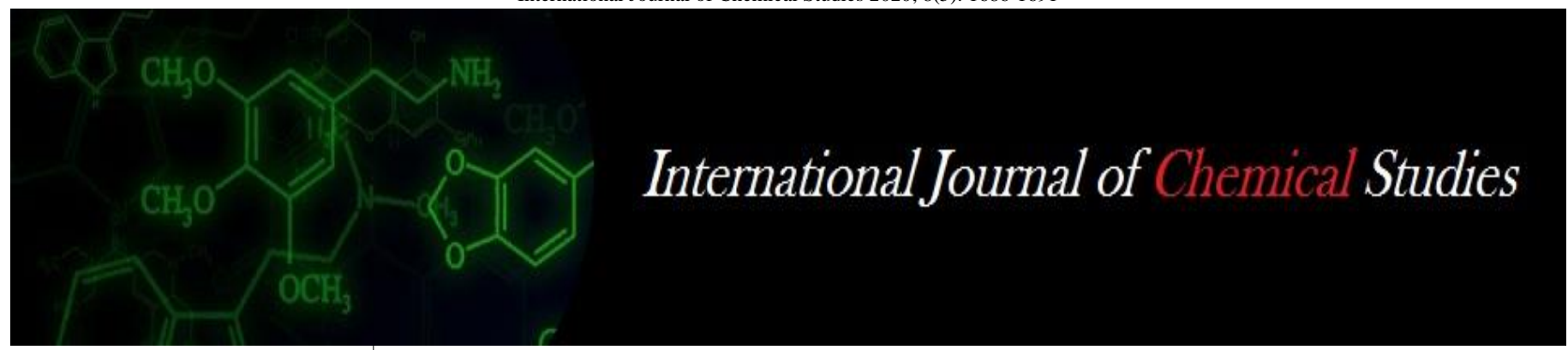

P-ISSN: 2349-8528

E-ISSN: 2321-4902

www.chemijournal.com

IJCS 2020; 8(5): 1686-1691

(C) 2020 IJCS

Received: 20-06-2020

Accepted: 18-07-2020

\section{KC Gajera}

Department of Agricultural

Chemistry \& Soil Science,

Junagadh Agricultural

University, Junagadh, Gujarat, India

\section{AV Rajani}

Department of Agricultural Chemistry \& Soil Science,

Junagadh Agricultural

University, Junagadh, Gujarat,

India

\section{LC Vekaria}

Department of Agricultural Chemistry \& Soil Science,

Junagadh Agricultural

University, Junagadh, Gujarat,

India

\section{AA Maheta}

Department of Agricultural Chemistry \& Soil Science, Junagadh Agricultural

University, Junagadh, Gujarat, India
Corresponding Author: KC Gajera

Department of Agricultural

Chemistry \& Soil Science,

Junagadh Agricultural

University, Junagadh, Gujarat, India

\section{Consequence of long-term balance nutrient management on soil nitrogen dynamics under groundnut-wheat cropping sequence in a calcareous clay Soils}

\author{
KC Gajera, AV Rajani, LC Vekaria and AA Maheta
}

DOI: https://doi.org/10.22271/chemi.2020.v8.i5w.10541

\begin{abstract}
The application of FYM maintained or increased nitrogen status of LTFE soils. In treatments of FYM $\left(\mathrm{T}_{8}, \mathrm{~T}_{9}\right)$, the status of nitrogen fractions increased. In case of all the fractions of nitrogen found significantly maximum in $\mathrm{T}_{9}$. At initial stage of experiment $\left(1^{\text {st }}\right.$ year $)$ available nitrogen status of LTFE soils falls under lower range $\left(<250 \mathrm{Kg} \mathrm{N} \mathrm{ha}^{-1}\right)$, also after $5^{\text {th }}, 10^{\text {th }}, 15^{\text {th }}$ and $20^{\text {th }}$ year it decreased to lower range $\left(<250 \mathrm{Kg} \mathrm{N} \mathrm{ha}^{-1}\right)$ in most of the treatments, except treatments which received FYM $\left(\mathrm{T}_{8} \& \mathrm{~T}_{9}\right)$ which showed medium range in available-N status of LTFE soils. Further It was established here that for maintaining $\mathrm{N}$ fertility of soil at long run, addition of FYM is essential with inorganic fertilizers. Similar results were also recorded in case of all other fractions of nitrogen. In LTFE soils the percent depletion of different forms of nitrogen was interesting under all treatments. The total-N and O. C. showed positive depletion after a span of 20 year except $\mathrm{T}_{1}, \mathrm{~T}_{5}, \mathrm{~T}_{6}$ and $\mathrm{T}_{9}$ and available-N exhibited positive depletion except treatment $\mathrm{T}_{1}, \mathrm{~T}_{5}$ and $\mathrm{T}_{6}$.
\end{abstract}

Keywords: Nitrogen fraction, total nitrogen, ammonical nitrogen, nitrate nitrogen, O.C., available nitrogen, AICRP-LTFE soils, dynamics, fractions, haplustepts

\section{Introduction}

Nitrogen is an important element for plant life. In the importance it comes only next to carbon, hydrogen and oxygen as it figures in the composition of proteins, nucleic acid, growth hormones, vitamins etc. It is also one of the main structural components of a living organism. Only a small proportion of total $\mathrm{N}$ is present in the available forms $\left(\mathrm{NH}_{4+}\right.$ andNO$\left.{ }_{3}\right)$ in the soil. Nitrate is first reduced to ammonium level in a series of steps in order to be absorbed by the plants. The average Indian soil contains about 0.05 per cent nitrogen. Nitrogen occurs in soil as inorganic and organic compounds. Nitrates and nitrites of calcium, potassium etc. are the main inorganic forms of nitrogen while organic form chiefly the proteins. The mineral $\mathrm{N}$ of the soil exists as $\mathrm{NH}_{4+}, \mathrm{NO}_{-3}$ and sometimes $\mathrm{NO}_{2}$ - either in soil solution, on exchange sites of soil particles or as $\mathrm{NH}_{4+}$ held by clay minerals. Some gaseous nitrogen may also be found in the soils atmosphere and dissolved in soil solution. In most of the soils, the bulk of nitrogen is as an organic form and usually near the surface. The inorganic forms of nitrogen include nitrite which is usually a transitional stage between nitrate and ammonium, and is easily removed. Nitrogen also occurs as exchangeable ions, fixed forms and traces of gaseous forms such as dinitrogen and nitrogen monoxide and elemental nitrogen. Considering this fact, there is a urgent need to study the dynamics of different fractions of nitrogen under intensive cropping system and hence, the present investigation was planned.

\section{Materials and Methods}

Surface soil samples $(0-15 \mathrm{~cm})$ were collected from the AICRP-LTFE soils conducted on groundnut-wheat sequence in Randomized Block Design replicated four times at Instructional Farm Junagadh Agricultural University, Junagadh during the year 1999-2000 (1 ${ }^{\text {st }}$ year, after wheat $), 2003-04$ ( $5^{\text {th }}$ year, after wheat $), 2008-09$ (10 ${ }^{\text {th }}$ year, after wheat $), 2013-14\left(15^{\text {th }}\right.$ year, after wheat) and 2018-19 (20 th year, after wheat). The treatments were $\mathrm{T}_{1}-50 \%$ NPK of recommended doses in G'nut-wheat sequence, $\mathrm{T}_{2}-100 \%$ NPK of recommended doses in 
G'nut -wheat sequence, $\mathrm{T}_{3^{-}} 150 \%$ NPK of recommended doses in G'nut -wheat sequence, $\mathrm{T}_{4^{-}} 100 \%$ NPK of recommended doses in G'nut -wheat sequence + $\mathrm{ZnSO} 4$ @ $50 \mathrm{~kg} \mathrm{ha}^{-1}$ once in three year to G'nut only (i.e. '99, 02, 05 etc.), $\mathrm{T}_{5}-\mathrm{NPK}$ as per soil test, $\mathrm{T}_{6}-100 \% \mathrm{NP}$ of recommended doses in G'nut -wheat sequence, $\mathrm{T}_{7-} 100 \% \mathrm{~N}$ of recommended doses in G'nut wheat sequence, $\mathrm{T}_{8}-50 \%$ NPK of recommended doses + FYM @ $10 \mathrm{t} \mathrm{ha}^{-1}$ to G'nut and $100 \%$ NPK to wheat, T $^{-}$Only FYM @ $10 \mathrm{t} \mathrm{ha}^{-1}$ to Groundnut and @ $15 \mathrm{t} \mathrm{ha}^{-1}$ to wheat, $\mathrm{T}_{10^{-}} 50 \% \mathrm{NPK}$ of recommended doses + Rhizobium + PSM to G'nut and $100 \%$ NPK to wheat, $\mathrm{T}_{11^{-}} 100 \%$ NPK of recommended doses in G'nut -wheat sequence ( $\mathrm{P}$ as $\mathrm{SSP}$ ) and $\mathrm{T}_{12^{-}}$Control. These soil samples were analyzed to determine the different forms of nitrogen on the basis of method mentioned below.

\section{Total nitrogen}

Total nitrogen was determined by the modified Kjeldhal method (Jackson, 1973) ${ }^{[6]}$.

\section{Available nitrogen}

Available nitrogen was determined by alkaline permanganate method (Subbiah and Asija, 1956) ${ }^{[15]}$.

\section{Ammonical nitrogen}

Ammonical nitrogen was determined by Richardson's method (Richardson, 1938) ${ }^{[13]}$ N.B. - It's modification of Olsen method.

\section{Nitrate nitrogen}

Nitrate nitrogen was determined after Olsens extraction for ammonia (Olsen, 1929) ${ }^{[11]}$

\section{Organic carbon}

Organic carbon was determined by wet oxidation method
(Walkley \& Black, 1935) ${ }^{[19]}$. Also detail information of analysis of the $\mathrm{N}$ fractions that I have been taken from the Comprehension Book of Soil Science Laboratory Analysis (Ashokkumar V. Rajani, 2018) ${ }^{[1]}$.

Depletion (\%): These nutrients depleted from soil by different cycles were calculated by the formula:

$\begin{gathered}\text { Depletion of } \\ \text { nutrient (\%) }\end{gathered}$
$\begin{gathered}\text { Nutrient status } \\ \text { of index year }\end{gathered} \quad \begin{gathered}\text { Nutrient status } \\ \text { of final year }\end{gathered}$
Nutrient status of index year

\section{Results and Discussion}

The results obtained from the present investigation have been discussed below

\section{Available nitrogen}

The Available nitrogen status of LTFE soils showed significant difference among the treatments in $1^{\text {st }}$ year, $5^{\text {th }}$ year, $10^{\text {th }}$ year, $15^{\text {th }}$ year, $20^{\text {th }}$ year and pooled over the years. (Table 1) The significant highest value of available $\mathrm{N}$ content was recorded in treatments which received FYM $\left(\mathrm{T}_{9}\right)$ in pooled over years. During initial year $\left(1^{\text {st }}\right.$ year $)$, highest value observed in $\mathrm{T}_{9}$ followed by $\mathrm{T}_{8}$. This result was in confirmation with the finding of Varalakshmi et al. (2005) ${ }^{[17]}$ who reported that available $\mathrm{N}$ significantly improved with the use of $100 \%$ recommended fertilizer $+7.5 \mathrm{t} \mathrm{FYM} \mathrm{ha}^{-1}$ in groundnut-finger millet cropping system and it was highest in $\mathrm{T}_{9}$ during the $10^{\text {th }}, 15^{\text {th }}$ and $20^{\text {th }}$ year except $5^{\text {th }}$ year in which it was highest in $\mathrm{T}_{8}$. There was slight increase in available-N content during $10^{\text {th }}$ year and $20^{\text {th }}$ year as compared to the initial year $\left(1^{\text {st }}\right.$ year) value. The FYM having the positive surplus residual effect on the available- $\mathrm{N}$ content in the soil.

Table 1: Status of Available-N ( $\left.\mathrm{kg} \mathrm{ha}^{-1}\right)$ in soils of LTFE in $1^{\text {st }}, 5^{\text {th }}, 10^{\text {th }}, 15^{\text {th }}$ and $20^{\text {th }}$ year

\begin{tabular}{|c|c|c|c|c|c|c|}
\hline \multirow{2}{*}{ Treat. } & \multicolumn{6}{|c|}{ Available-N (kg ha-1) } \\
\hline & $1^{\text {st }}$ year & $5^{\text {th }}$ year & $10^{\text {th }}$ year & $15^{\text {th }}$ year & $20^{\text {th }}$ year & Pooled \\
\hline $\mathrm{T}_{1}$ & 187.64 & 199.10 & 220.74 & 226.01 & 247.10 & 216.12 \\
\hline $\mathrm{T}_{2}$ & 233.01 & 219.60 & 205.62 & 215.43 & 221.25 & 218.98 \\
\hline $\mathrm{T}_{3}$ & 199.02 & 202.12 & 230.96 & 219.69 & 190.14 & 208.39 \\
\hline $\mathrm{T}_{4}$ & 210.29 & 191.39 & 191.22 & 197.08 & 184.92 & 194.98 \\
\hline $\mathrm{T}_{5}$ & 202.03 & 223.59 & 223.85 & 210.21 & 229.75 & 217.89 \\
\hline $\mathrm{T}_{6}$ & 217.27 & 214.43 & 214.95 & 224.31 & 234.59 & 221.11 \\
\hline $\mathrm{T}_{7}$ & 199.00 & 186.82 & 196.88 & 190.37 & 193.62 & 193.34 \\
\hline $\mathrm{T}_{8}$ & 258.89 & 281.91 & 273.49 & 151.22 & 257.31 & 244.56 \\
\hline $\mathrm{T}_{9}$ & 271.03 & 276.33 & 283.92 & 240.64 & 269.31 & 268.24 \\
\hline $\mathrm{T}_{10}$ & 223.81 & 189.34 & 240.12 & 243.26 & 206.67 & 220.64 \\
\hline $\mathrm{T}_{11}$ & 222.50 & 227.87 & 209.48 & 170.97 & 204.25 & 207.01 \\
\hline $\mathrm{T}_{12}$ & 166.43 & 167.92 & 190.45 & 183.42 & 162.11 & 174.07 \\
\hline Mean & 215.91 & 215.03 & 223.47 & 206.05 & 216.75 & 215.44 \\
\hline S.Em. \pm & 7.57 & 8.48 & 8.75 & 11.71 & 7.39 & 3.99 \\
\hline C.D. at $5 \%$ & 21.78 & 24.40 & 25.17 & 33.71 & 21.25 & 11.14 \\
\hline C.V.\% & 7.01 & 7.89 & 7.83 & 11.37 & 6.82 & 8.28 \\
\hline $\mathrm{Y} * \mathrm{~T}$ & \multicolumn{3}{|c|}{ S.Em. \pm 8.92} & \multicolumn{3}{|c|}{ C.D. at $5 \% 24.89$} \\
\hline
\end{tabular}

\section{Total nitrogen}

Status of total nitrogen in LTFE soils was almost same, but it was affected significantly and found significant differences due to various treatments in $1^{\text {st }}, 5^{\text {th }}, 10^{\text {th }}, 15^{\text {th }}, 20^{\text {th }}$ year and when pooled over years (Table 2). The highest value of total nitrogen $(\%)$ recorded in $\mathrm{T}_{8}(50 \% \mathrm{~N} \mathrm{P} \mathrm{K}$ of recommended doses + FYM@10 t/ha to G'nut and 100\% NPK to Wheat)during $1^{\text {st }}$ year, $5^{\text {th }}$ year and $10^{\text {th }}$ year, the results are supported by Meena et al. (2019) ${ }^{[10]}$ investigated that the highest total nitrogen was observed under application of $100 \%$ NPK + FYM $10 \mathrm{t} \mathrm{ha}^{-1}$ in soil under long term maizewheat cropping sequence. Khandagle et al. (2019) ${ }^{[8]}$ also reported similar result under the same treatment. Kaur and Singh (2014) ${ }^{[7]}$ also found that the increase in total N $23.1 \%$ more in FYM application than inorganic fertilizer alone. Total-N found highest in $\mathrm{T}_{9}$ (Only FYM @ $10 \mathrm{t} \mathrm{ha}^{-1}$ to Groundnut and @ $15 \mathrm{tha}^{-1}$ to wheat) during $15^{\text {th }}$ year and $20^{\text {th }}$ year. Pooled value of treatments $\mathrm{T}_{8}$ was highest followed by 
$\mathrm{T}_{9}$. The Year $\mathrm{x}$ treatment interaction was also found significant. The result are supported by Fengmin et al. (1998) ${ }^{[5]}$ investigated the effect of organic matter on nitrogen content in soils derived from loess in NW China. The results indicated that Available $\mathrm{N}$ and Total $\mathrm{N}$ content were correlated positively and significantly with organic matter content. But here it was interesting that in $\mathrm{T}_{10}$ Total-N status of that soil improved in case of the pooled result,that might be due to fixation of atmospheric nitrogen by Rhizobium bacteria.

Table 2: Status of Total-N (\%) in soils of LTFE in $1^{\text {st }}, 5^{\text {th }}, 10^{\text {th }}, 15^{\text {th }}$ and $20^{\text {th }}$ year

\begin{tabular}{|c|c|c|c|c|c|c|}
\hline \multirow{2}{*}{ Treat. } & \multicolumn{6}{|c|}{ Total-N (\%) } \\
\hline & $1^{\text {st }}$ year & $5^{\text {th }}$ year & $10^{\text {th }}$ year & $15^{\text {th }}$ year & $20^{\text {th }}$ year & Pooled \\
\hline $\mathrm{T}_{1}$ & 0.0544 & 0.0588 & 0.0625 & 0.0666 & 0.0688 & 0.0622 \\
\hline $\mathrm{T}_{2}$ & 0.0647 & 0.0657 & 0.0585 & 0.0637 & 0.0612 & 0.0628 \\
\hline $\mathrm{T}_{3}$ & 0.0599 & 0.0602 & 0.0654 & 0.0608 & 0.0529 & 0.0598 \\
\hline $\mathrm{T}_{4}$ & 0.0635 & 0.0614 & 0.0526 & 0.0561 & 0.0510 & 0.0569 \\
\hline $\mathrm{T}_{5}$ & 0.0618 & 0.0608 & 0.0621 & 0.0580 & 0.0643 & 0.0614 \\
\hline $\mathrm{T}_{6}$ & 0.0598 & 0.0624 & 0.0603 & 0.0628 & 0.0652 & 0.0621 \\
\hline $\mathrm{T}_{7}$ & 0.0627 & 0.0590 & 0.0549 & 0.0633 & 0.0538 & 0.0587 \\
\hline $\mathrm{T}_{8}$ & 0.0768 & 0.0853 & 0.0818 & 0.0741 & 0.0750 & 0.0786 \\
\hline $\mathrm{T}_{9}$ & 0.0719 & 0.0837 & 0.0770 & 0.0804 & 0.0774 & 0.0781 \\
\hline $\mathrm{T}_{10}$ & 0.0663 & 0.0645 & 0.0672 & 0.0706 & 0.0577 & 0.0653 \\
\hline $\mathrm{T}_{11}$ & 0.0669 & 0.0646 & 0.0583 & 0.0626 & 0.0571 & 0.0619 \\
\hline $\mathrm{T}_{12}$ & 0.0550 & 0.0527 & 0.0530 & 0.0510 & 0.0543 & 0.0532 \\
\hline Mean & 0.0636 & 0.0649 & 0.0628 & 0.0642 & 0.0616 & 0.0634 \\
\hline S.Em. \pm & 0.0020 & 0.0016 & 0.0021 & 0.0021 & 0.0018 & 0.0009 \\
\hline C.D. at $5 \%$ & 0.0059 & 0.0047 & 0.0061 & 0.0059 & 0.0053 & 0.0024 \\
\hline C.V.\% & 6.43 & 5.02 & 6.76 & 6.44 & 5.99 & 6.15 \\
\hline $\mathrm{Y} * \mathrm{~T}$ & \multicolumn{2}{|c|}{ S.Em. \pm 0.0019} & \multicolumn{4}{|c|}{ C.D. at $5 \% 0.0054$} \\
\hline
\end{tabular}

\section{Organic carbon (O.C.)}

The Organic carbon showed significant difference in $1^{\text {st }}$ year, $5^{\text {th }}$ year, $10^{\text {th }}$ year, $15^{\text {th }}$ year, $20^{\text {th }}$ year and pooled result and it was recorded higher under application of $50 \%$ NPK of recommended doses +FYM@10 t/ha to G'nut and 100\% NPK to Wheat $\left(\mathrm{T}_{8}\right)$ followed by $\left(\mathrm{T}_{9}\right)$ Only FYM @ $10 \mathrm{t} \mathrm{ha}^{-1}$ to Groundnut and @ $15 \mathrm{t} \mathrm{ha}^{-1}$ to wheat (Table 3) In case of pooled results and also higher in the treatment $\mathrm{T}_{8}$ during $1^{\text {st }}$, $5^{\text {th }}$ and $10^{\text {th }}$ year result. The results are supported by Patel et al. (2018) ${ }^{[12]}$ who observed that the significant increase in soil organic carbon was recorded with 100\% NPK + FYM @ 15 t $\mathrm{ha}^{-1}$ in the 41-year old LTFE in a Vertisol under soybeanwheat cropping system. Year $\mathrm{x}$ treatment interaction also found significant. During $15^{\text {th }}$ and $20^{\text {th }}$ year the Organic carbon was higher in T9 (Only FYM @ $10 \mathrm{t} \mathrm{ha}^{-1}$ to Groundnut and @ $15 \mathrm{t} \mathrm{ha}^{-1}$ to wheat) and that might be increase in LTFE surface soil after $20^{\text {th }}$ year due to FYM. The results are supported by Balaguravaih et al. (2005) ${ }^{[3]}$ investigated that application of FYM or groundnut shells alone improved the O. C. status marginally. There was increase in O. C. status of LTFE soils at $5^{\text {th }}$ and $15^{\text {th }}$ year as compared to initial status of soil ( $1^{\text {st }}$ year). FYM application improved soil physical condition, ultimately root growth increases and more biomass added to the soil, seems to increases organic carbon status of the particular soil.

Table 3: Status of O.C. $(\%)$ in soils of LTFE in $1^{\text {st }}, 5^{\text {th }}, 10^{\text {th }}, 15^{\text {th }}$ and $20^{\text {th }}$ year

\begin{tabular}{|c|c|c|c|c|c|c|}
\hline \multirow{2}{*}{ Treat. } & \multicolumn{6}{|c|}{ O.C. (\%) } \\
\hline & $1^{\text {st }}$ year & $5^{\text {th }}$ year & $10^{\text {th }}$ year & $15^{\text {th }}$ year & $20^{\text {th }}$ year & Pooled \\
\hline $\mathrm{T}_{1}$ & 0.625 & 0.673 & 0.718 & 0.763 & 0.790 & 0.714 \\
\hline $\mathrm{T}_{2}$ & 0.745 & 0.755 & 0.665 & 0.730 & 0.703 & 0.720 \\
\hline $\mathrm{T}_{3}$ & 0.690 & 0.690 & 0.748 & 0.698 & 0.598 & 0.685 \\
\hline $\mathrm{T}_{4}$ & 0.728 & 0.705 & 0.603 & 0.643 & 0.580 & 0.652 \\
\hline $\mathrm{T}_{5}$ & 0.710 & 0.698 & 0.713 & 0.665 & 0.733 & 0.704 \\
\hline $\mathrm{T}_{6}$ & 0.688 & 0.718 & 0.688 & 0.720 & 0.748 & 0.712 \\
\hline $\mathrm{T}_{7}$ & 0.723 & 0.678 & 0.625 & 0.725 & 0.613 & 0.673 \\
\hline $\mathrm{T}_{8}$ & 0.885 & 0.983 & 0.940 & 0.853 & 0.858 & 0.904 \\
\hline $\mathrm{T}_{9}$ & 0.828 & 0.963 & 0.885 & 0.925 & 0.880 & 0.896 \\
\hline $\mathrm{T}_{10}$ & 0.763 & 0.740 & 0.768 & 0.810 & 0.653 & 0.747 \\
\hline $\mathrm{T}_{11}$ & 0.770 & 0.740 & 0.665 & 0.713 & 0.648 & 0.707 \\
\hline $\mathrm{T}_{12}$ & 0.633 & 0.603 & 0.603 & 0.580 & 0.613 & 0.606 \\
\hline Mean & 0.732 & 0.745 & 0.718 & 0.735 & 0.701 & 0.726 \\
\hline S.Em. \pm & 0.024 & 0.019 & 0.024 & 0.024 & 0.021 & 0.010 \\
\hline C.D. at $5 \%$ & 0.068 & 0.055 & 0.069 & 0.069 & 0.061 & 0.028 \\
\hline C.V.\% & 6.46 & 5.13 & 6.70 & 6.51 & 6.06 & 6.19 \\
\hline $\mathrm{Y} * \mathrm{~T}$ & \multicolumn{2}{|c|}{ S.Em. \pm 0.023} & \multicolumn{4}{|c|}{ C.D. at $5 \% 0.063$} \\
\hline
\end{tabular}

\section{Ammonical nitrogen}

The Ammonical nitrogen showed significant difference due to treatments in $1^{\text {st }}$ year, $5^{\text {th }}$ year, $10^{\text {th }}$ year, $15^{\text {th }}$ year, $20^{\text {th }}$ year and pooled result, the $\mathrm{Y} \times \mathrm{T}$ interaction was also found significant. In first year, the highest value was recorded in plot of $T_{8}$ followed by $T_{9}, T_{2}$ and $T_{11}$, The results are supported by earlier works of Venugopal et al. (2017) ${ }^{[18]}$ investigated that the application of FYM along with NPK 
resulted in higher $\mathrm{NH}_{4}-\mathrm{N}$ (28 $\mathrm{mg} \mathrm{kg}^{-1}$ ) than application of only NPK, while in $5^{\text {th }}$ year, $10^{\text {th }}$ year, $15^{\text {th }}$ year and $20^{\text {th }}$ year the highest value was recorded in treatment $\mathrm{T}_{11}, \mathrm{~T}_{8}, \mathrm{~T}_{10}$, and $\mathrm{T}_{5}$ respectively. In case of $\mathrm{T}_{10}(50 \% \mathrm{NPK}$ of recommended doses + Rhizobium + PSM to G'nut and $100 \%$ NPK to Wheat) high result might be due to nitrogen fixation by microorganism. In case of $\mathrm{T}_{11}(100 \%$ NPK of recommended doses in G'nut Wheat sequence $\mathrm{P}$ as SSP) which include sulphur in SSP which help the plant to grow their roots more efficiently and so more nitrogen fixation might be done and $\mathrm{T}_{5}$ (NPK as per Soil Test) having more ammonical-N might be due to low crop yield.

Here the treatment $\left(\mathrm{T}_{8}, \mathrm{~T}_{9}\right)$ received $\mathrm{FYM}$ having higher ammonical-N content in the pooled value. The results are supported by earlier work by Kushwaha (2011) ${ }^{[9]}$ the highest value of inorganic-N $188 \mathrm{~kg} \mathrm{ha}^{-1}$ was recorded with $100 \%$ $\mathrm{NPK}+\mathrm{FYM}$ treatment. As a result of fertilizer application in these treatments in surface and subsurface soil positive effect of FYM. FYM is the food for the microorganism which help to growth of nitrogen fixing organism and also release organic acid upon decomposition which might be release unavailable form of nitrogen. There was a slight decreaseed in Ammonical nitrogen status of the LTFE soil as compared to the initial status (Table 4.1.3 \& Fig. 4.1.3). The results are supported by earlier works of Sihag et al. (2005) ${ }^{[14]}$, Balagopalan et al. (1986) ${ }^{[2]}$, who observed that surface soil samples showed decrease in $\mathrm{NH}_{4}-\mathrm{N}$.

Table 4: Status of Ammonical-N (ppm) in soils of LTFE in $1^{\text {st }}, 5^{\text {th }}, 10^{\text {th }}, 15^{\text {th }}$ and $20^{\text {th }}$ year

\begin{tabular}{|c|c|c|c|c|c|c|}
\hline \multirow{2}{*}{ Treat. } & \multicolumn{6}{|c|}{ Ammonical-N (ppm) } \\
\hline & 1 $^{\text {st }}$ year & $5^{\text {th }}$ year & $10^{\text {th }}$ year & $15^{\text {th }}$ year & $20^{\text {th }}$ year & Pooled \\
\hline $\mathrm{T}_{1}$ & 43.25 & 45.25 & 52.00 & 53.25 & 57.25 & 50.20 \\
\hline $\mathrm{T}_{2}$ & 56.00 & 56.25 & 47.00 & 49.25 & 51.00 & 51.90 \\
\hline $\mathrm{T}_{3}$ & 43.00 & 46.25 & 52.75 & 44.75 & 43.75 & 46.10 \\
\hline $\mathrm{T}_{4}$ & 48.00 & 33.25 & 61.00 & 44.25 & 41.75 & 45.65 \\
\hline $\mathrm{T}_{5}$ & 48.00 & 55.25 & 45.50 & 49.50 & 59.75 & 51.60 \\
\hline $\mathrm{T}_{6}$ & 46.50 & 50.00 & 49.50 & 53.75 & 54.00 & 50.75 \\
\hline $\mathrm{T}_{7}$ & 43.50 & 36.50 & 42.00 & 28.75 & 40.25 & 38.20 \\
\hline $\mathrm{T}_{8}$ & 58.75 & 66.00 & 61.25 & 33.25 & 59.00 & 55.65 \\
\hline $\mathrm{T}_{9}$ & 56.75 & 58.50 & 56.75 & 48.00 & 58.75 & 55.75 \\
\hline $\mathrm{T}_{10}$ & 37.50 & 41.25 & 54.00 & 55.75 & 31.50 & 44.00 \\
\hline $\mathrm{T}_{11}$ & 51.75 & 73.50 & 50.75 & 48.25 & 36.75 & 52.20 \\
\hline $\mathrm{T}_{12}$ & 34.25 & 37.75 & 41.50 & 22.25 & 24.50 & 32.05 \\
\hline Mean & 47.27 & 49.98 & 51.17 & 44.25 & 46.52 & 47.84 \\
\hline S.Em. \pm & 2.44 & 2.00 & 2.79 & 2.74 & 1.87 & 1.07 \\
\hline C.D. at $5 \%$ & 7.02 & 5.77 & 8.03 & 7.87 & 5.39 & 2.99 \\
\hline C.V.\% & 10.32 & 8.02 & 10.90 & 12.36 & 8.06 & 10.02 \\
\hline $\mathrm{Y} * \mathrm{~T}$ & \multicolumn{2}{|c|}{ S.Em. \pm 2.39} & \multicolumn{4}{|c|}{ C.D. at 5\%6.69 } \\
\hline
\end{tabular}

\section{Nitrate nitrogen}

The data presented in table-5 depicted that there were significant differences found in status of Nitrate-N in LTFE soils at initial $\left(1^{\text {st }}\right.$ year), after $5^{\text {th }}, 10^{\text {th }}, 15^{\text {th }}$ and $20^{\text {th }}$ year, due to various treatments but, that was non significant for the pooled data. The $\mathrm{Y} \times \mathrm{T}$ interaction showed significant difference among treatments. Initially $\left(1^{\text {st }}\right.$ year $)$ and in $5^{\text {th }}$ year the highest value recorded in plot of $\mathrm{T}_{11}(100 \%$ NPK of recommended doses in G'nut -Wheat sequence $\mathrm{P}$ as SSP), that add sulphur to the soil due to SSP and it was best for the root growth and nitrogen fixation, after that it was highest in $\mathrm{T}_{9}$, $\mathrm{T}_{10}$ and $\mathrm{T}_{8}$ during the year $10^{\text {th }}$ year, $15^{\text {th }}$ year and $20^{\text {th }}$ year respectively. High nitrate-N in $(50 \% \mathrm{NPK}+$ Rhizobium +
PSM to groundnut and $100 \%$ NPK to wheat $\left(\mathrm{T}_{10}\right)$, it might be due to fixation of atmospheric nitrogen by Rhizobium bacteria. The treatment $\mathrm{T}_{8}$ which receive FYM having high nitrate-N due to effect of FYM. The results are supported by earlier work by Venugopal et al. (2017) ${ }^{[18]}$ Found that the application of FYM along with NPK resulted in higher $\mathrm{NO}_{3}$ $\mathrm{N}$ (19.7 $\mathrm{mg} \mathrm{kg}^{-1}$ ) than application of only NPK. Kushwaha (2011) ${ }^{[9]}$ also studied Positive effect of FYM.

There was marginal increase after $1^{\text {st }}$ year upto $5^{\text {th }}$ year but after that overall decrease in status of Nitrate-N in $10^{\text {th }}, 15^{\text {th }}$ and $20^{\text {th }}$ year as compare to initial value and Balagopalan et al. (1986) ${ }^{[2]}$ also reported similar results $i$. e. overall decrease of nitrate nitrogen in surface soil samples.

Table 5: Status of Nitrate-N (ppm) in soils of LTFE in $1^{\text {st }}, 5^{\text {th }}, 10^{\text {th }}, 15^{\text {th }}$ and $20^{\text {th }}$ year

\begin{tabular}{|c|c|c|c|c|c|c|}
\hline \multirow{2}{*}{ Treat. } & \multicolumn{7}{|c|}{ Nitrate-N $(\mathbf{p p m})$} \\
\cline { 2 - 7 } & $\mathbf{1}^{\text {st }}$ year & $\mathbf{5}^{\text {th }}$ year & $\mathbf{1 0}^{\text {th }}$ year & $\mathbf{1 5}^{\text {th}}$ year & $\mathbf{2 0}^{\text {th }}$ year & Pooled \\
\hline $\mathrm{T}_{1}$ & 21.25 & 22.25 & 24.00 & 24.50 & 27.50 & 23.90 \\
\hline $\mathrm{T}_{2}$ & 26.75 & 29.75 & 20.25 & 23.75 & 21.00 & 24.30 \\
\hline $\mathrm{T}_{3}$ & 25.25 & 22.25 & 24.75 & 21.75 & 19.25 & 22.65 \\
\hline $\mathrm{T}_{4}$ & 23.00 & 13.25 & 23.50 & 21.50 & 18.25 & 19.90 \\
\hline $\mathrm{T}_{5}$ & 22.25 & 26.00 & 27.25 & 18.00 & 20.25 & 22.75 \\
\hline $\mathrm{T}_{6}$ & 28.25 & 28.25 & 21.75 & 19.00 & 26.25 & 24.70 \\
\hline $\mathrm{T}_{7}$ & 20.75 & 19.25 & 20.75 & 13.00 & 12.25 & 17.20 \\
\hline $\mathrm{T}_{8}$ & 27.25 & 33.75 & 29.25 & 15.75 & 28.00 & 26.80 \\
\hline $\mathrm{T}_{9}$ & 30.00 & 30.50 & 32.00 & 23.00 & 7.00 & 24.50 \\
\hline $\mathrm{T}_{10}$ & 19.75 & 18.25 & 27.00 & 30.75 & 21.00 & 23.35 \\
\hline $\mathrm{T}_{11}$ & 31.50 & 39.00 & 22.50 & 12.00 & 21.25 & 25.25 \\
\hline $\mathrm{T}_{12}$ & 16.50 & 17.50 & 16.25 & 19.50 & 14.00 & 16.75 \\
\hline Mean & 24.38 & 25.00 & 24.10 & 20.21 & 19.67 & 22.67 \\
\hline
\end{tabular}




\begin{tabular}{|c|c|c|c|c|c|c|}
\hline S.Em. \pm & 1.85 & 1.46 & 2.06 & 1.80 & 1.23 & 0.76 \\
\hline C.D. at 5\% & 5.32 & 4.20 & 5.91 & 5.18 & 3.54 & NS \\
\hline C.V.\% & 15.18 & 11.69 & 17.05 & 17.81 & 12.50 & 15.04 \\
\hline Y $*$ T & \multicolumn{6}{|c|}{ C.Em. \pm 1.70} \\
\hline \multicolumn{7}{|l}{}
\end{tabular}

\section{Depletion percent of different forms of nitrogen}

In LTFE soils after a span of twenty year the Total nitrogen showed positive depletion that means it decreased (Table 6) except in $T_{1}, T_{5}, T_{6}$ and $T_{9}$ were negative depletion was noted, Similar results were also found in case of O. C. percent depletion. These results were also in agreement with the finding of Tomar (2003) ${ }^{[16]}$ in his studies in Typic Haplustert clay soil following soybean-wheat crop sequence receiving inorganic fertilizers either or with FYM continuously for 31 years had observed that organic carbon content was $1.02 \%$ $(100 \% \mathrm{NPK}+\mathrm{FYM})$ as compared to $0.58 \%$ in control. Among various $\mathrm{N}$ fractions, amino acid nitrogen was dominant $\mathrm{N}$ fraction. Whereas Ammonical nitrogen showed positive trend in percent depletion, except in $\mathrm{T}_{1}, \mathrm{~T}_{3}, \mathrm{~T}_{5}, \mathrm{~T}_{6}, \mathrm{~T}_{8}$ and $\mathrm{T}_{9}$ were negative depletion was noted, the highest percent depletion of Ammonical $\mathrm{N}$ was noted in $\mathrm{T}_{11}$. In case of Nitrate nitrogen, all treatments exhibited positive depletion, except $\mathrm{T}_{1}, \mathrm{~T}_{8} \& \mathrm{~T}_{10}$, this might have been attributed to leaching losses and crop uptake mostly this form of nitrogen. In case of Available nitrogen, where the highest positive depletion was noted in treatment which $100 \%$ NPK of recommended doses in G'nut -Wheat sequence + $\mathrm{ZnSO}_{4} @ 50 \mathrm{~kg} \mathrm{ha}^{-1}$ once in three year to G'nut only $\left(\mathrm{T}_{4}\right)$ that was might be due to more uptake by the crop, negative depletionnoted in treatment $\mathrm{T}_{1}$, $\mathrm{T}_{5}$ and $\mathrm{T}_{6}$. These results were also in agreement with the finding of Brar and Dheri (2016) ${ }^{[4]}$ Application of fertilizers improved available $\mathrm{N}$ in soil. Integrated use of organic manures and inorganic fertilizers improved the $\mathrm{N}$ fractions in the soil. Treatment $\mathrm{T}_{8}$ and $\mathrm{T}_{9}$ which include FYM having good result as compared to the control.

Table 6: Percent depletion of different forms of nitrogen after ground nut-wheat sequence in LTFE soils

\begin{tabular}{|c|c|c|c|c|c|}
\hline Treat. & Total-N & O.C. & Amm.-N & Nitr.-N & Av.-N \\
\hline $\mathrm{T}_{1}$ & -26.40 & -26.40 & -32.37 & -29.41 & -31.69 \\
\hline $\mathrm{T}_{2}$ & 5.33 & 5.70 & 8.93 & 21.50 & 5.05 \\
\hline $\mathrm{T}_{3}$ & 11.78 & 13.41 & -1.74 & 23.76 & 4.47 \\
\hline $\mathrm{T}_{4}$ & 19.68 & 20.27 & 13.02 & 20.65 & 12.06 \\
\hline $\mathrm{T}_{5}$ & -3.99 & -3.17 & -24.48 & 8.99 & -13.72 \\
\hline $\mathrm{T}_{6}$ & -8.94 & -8.73 & -16.13 & 7.08 & -7.97 \\
\hline $\mathrm{T}_{7}$ & 14.27 & 15.22 & 7.47 & 40.96 & 2.70 \\
\hline $\mathrm{T}_{8}$ & 2.29 & 3.11 & -0.43 & -2.75 & 0.61 \\
\hline $\mathrm{T}_{9}$ & -7.63 & -6.34 & -3.52 & 76.67 & 0.63 \\
\hline $\mathrm{T}_{10}$ & 12.88 & 14.43 & 16.00 & -6.33 & 7.66 \\
\hline $\mathrm{T}_{11}$ & 14.60 & 15.91 & 28.99 & 32.54 & 8.20 \\
\hline $\mathrm{T}_{12}$ & 1.37 & 3.16 & 28.47 & 15.15 & 2.59 \\
\hline
\end{tabular}

\section{Conclusion}

It can be concluded from the LongTerm Fertilizer Experiment (LTFE) in Junagadh constituting medium black calcareous soil derived from Trap basalt that the soil available forms of the nitrogen ascribed depletion over time irrespective of fertilizer treatments, except in treatments which received FYM along with inorganic fertilizers. An application of FYM not only sustains fertility, but also increases soil fertility status as like here in $\mathrm{N}$ status of the LTFE soil. In treatments which received FYM, increased available-N status in LTFE soils. The combined application of FYM and inorganic fertilizers in continuous manner, have sustained the crop yield. The dynamics of nitrogen along with their forms exhibited variable trend, in general some forms exhibited negative trend and some of them ascribed positive trend with varying magnitude according to the soil.

\section{Reference}

1. Ashokkumar V Rajani. Detail information of analysis of the $\mathrm{N}$ fractions. Comprehension Book of Soil Science Laboratory Analysis, JAYA Publishing House, Delhi, India,2018.

2. Balagopalan M, Jose AI, Sharma JK, Nair CTS, Kedharnath S, Kondas S. Distribution of organic carbon and different forms of nitrogen in a natural forest and adjacent eucalypt plantation at Arippa, Kerala. Eucalypts in India. Past, present and future. Proceeding of the national seminar held at Kerala Forest Research Institute, Peechi, Kerala, India, 1984-1986, 112-119.

3. Balaguravaih D, Adinarayana G, Prathap S, Yellamanda Reddy T. Influence of long-term use of inorganic and organic manures on soil fertility and sustainability of rainfed groundnut in Alfisols. Journal of the Indian Society of Soil Science.2005; 53:608-611.

4. Brar BS, Dheri GS. Soil Nitrogen Fractions in Relation to Rice-Wheat Productivity: Effects of Long-Term Application of Mineral Fertilizers and Organic Manures. Journal of Crop Improvement. 2016; 30(4):399-420.

5. Fengmin L, Wang TC, Li FM, Jing C. Effect of organic matter and total amount and availability of nitrogen and phosphorus in loess soil of North West China. Common Soil Science Plant Anal.1998; 29:73-87.

6. Jackson ML. Soilchemical analysis. Prentice Hall of Indian Pvt. Ltd., New Delhi, 1973.

7. Kaur J, Singh JP. Long-term effects of continuous cropping and different nutrient management practices on the distribution of organic nitrogen in soil under ricewheat system. Plant soil and environment. 2014; 60(2):63-68.

8. Khandagle A, Dwivedi BS, Aher SB, Dwivedi AK, Yashona DS, Mohbe $\mathrm{S}$ et al. Distribution of nitrogen fractions under long term fertilizer and manure application in a vertisol, Bioscience Biotechnology Research Communications. 2019; 12(1):186-193.

9. Kushwaha Satybhan. Effect of long term application of fertilizers and manure on nitrogen fractions in a Vertisol. M.Sc. thesis JNKVV, Jabalpur, 2011.

10. Meena S, Bali B, Purohit HS, Jain HK, Meena RH. Study the Organic and Inorganic Fraction of Nitrogen in Soil under Long Term Maize-Wheat Cropping Sequence. International Journal of Current Microbiology and Applied Sciences. 2019; 8(2):242-256.

11. Olsen C. Nitrate nitrogen was determined after extractiontion for ammonia. Comptes Rendus des Travaux Laboratoire Carlsberg. 1929; 17:1-20.

12. Patel G, Dwivedi BS, Dwivedi AK, Thakur R, Singh M. Long-term Effect of Nutrient Management on Soil Biochemical Properties in a Vertisol under SoybeanWheat Cropping Sequence. Journal of the Indian Society of Soil Science. 2018; 66(2):215-221.

13. Richardson HL. The determination of ammonical nitrogen. Journal of Agricultural Science. 1938; 28:73121. 
14. Sihag D, Singh JP, Mehla DS, Bhardwaj KK. Effect of integrated use of inorganic fertilizers and organic materials on the distribution of different forms of nitrogen and phosphorus in soil. Journal of the Indian Society of Coastal Agricultural Research.2005; 53:80-84.

15. Subbiah BV, Asija GL. A rapid procedure for the estimation of available nitrogen in soils. Cure Science. 1956; 25:254-260.

16. Tomar VK. Spatial distribution of inorganic and organic content of $\mathrm{P}$ and $\mathrm{S}$ as influenced by long term application of fertilizers and manure in Typic haplustert. M.Sc. Agri. Thesis, J. N. K. V. V. Jabalpur, M.P, 2003.

17. Varalakshmi LR, Srinivasmurthy CA, Bhaskar S.Effect of integrated use of organic manures and inorganic fertilizers on organic carbon, available $\mathrm{N}, \mathrm{P}$ and $\mathrm{K}$ in sustaining productivity of groundnut-finger millet cropping system. Journal of the Indian Society of Soil Science. 2005; 53:315-318.

18. Venugopal G, Sharma SHK, Qureshi AA, Sagar VGECh. Inorganic Fractions of Nitrogen and Phosphorus in Soils and Nitrogen, Phosphorus Uptake by Sorghum under Long Term Fertilization and Manuring. Research Journal of Agricultural Sciences. 2017; 8(5):1122-1126.

19. Walkley A, Black IA. An examination of methods for determining organic carbon and nitrogen in soils. Journal of Agriculture Science. 1935; 25:589-609. 